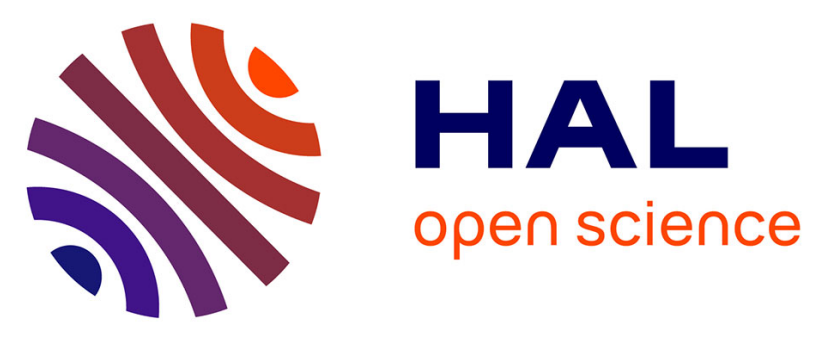

\title{
Differential susceptibility to the mycoparasite Paraphaeosphaeria minitans among Sclerotinia sclerotiorum isolates
}

Philippe C. Nicot, Félicie Avril, Magali Duffaud, Christel Leyronas, Claire Troulet, François Villeneuve, Marc Bardin

\section{To cite this version:}

Philippe C. Nicot, Félicie Avril, Magali Duffaud, Christel Leyronas, Claire Troulet, et al.. Differential susceptibility to the mycoparasite Paraphaeosphaeria minitans among Sclerotinia sclerotiorum isolates. Tropical Plant Pathology, 2019, 44 (1), pp.82-93. 10.1007/s40858-018-0256-7 . hal-02623473

\section{HAL Id: hal-02623473 \\ https://hal.inrae.fr/hal-02623473}

Submitted on 26 May 2020

HAL is a multi-disciplinary open access archive for the deposit and dissemination of scientific research documents, whether they are published or not. The documents may come from teaching and research institutions in France or abroad, or from public or private research centers.
L'archive ouverte pluridisciplinaire HAL, est destinée au dépôt et à la diffusion de documents scientifiques de niveau recherche, publiés ou non, émanant des établissements d'enseignement et de recherche français ou étrangers, des laboratoires publics ou privés.

\section{(ㅇ)(1) $\$$}

Distributed under a Creative Commons Attribution - NonCommercial - NoDerivatives| 4.0 
Original article

Differential susceptibility to the mycoparasite Paraphaeosphaeria minitans among Sclerotinia sclerotiorum isolates

Philippe C. Nicot ${ }^{1 *}$, Félicie Avril ${ }^{1}$, Magali Duffaud ${ }^{1}$, Christel Leyronas $^{1}$, Claire Troulet $^{1}$, François Villeneuve ${ }^{2}$, Marc Bardin ${ }^{1}$

${ }^{1}$ Pathologie végétale, INRA, 84140 Montfavet, France

${ }^{2}$ CTIFL, centre de Lanxade, 28 Route des Nébouts, F-24130 Prigonrieux, France

*corresponding author: philippe.nicot@inra.fr

Key words: biological control, Coniothyrium, hyperparasite, durability, sclerotia, white mold

Article Type: Original article

Submitted:

Accepted:

Section Editor: Flávio H. V. Medeiros

\begin{abstract}
The mycoparasitic fungus Paraphaeosphaeria minitans (formerly Coniothyrium minitans), is increasingly used by farmers to reduce soilborne inoculum of Sclerotinia sclerotiorum. In France, its field efficacy tends to be higher in the North than in the South, leading to the hypothesis of possible regional differences in the susceptibility of the pathogen to the biocontrol agent. A standardized assay was developed and four quantitative criteria were used to assess
\end{abstract}


the susceptibility to $P$. minitans of 75 S. sclerotiorum isolates collected from different regions of France. There was no significant difference between the group of isolates from the North and that from the South, but wide differences were observed among isolates, with consistent responses for all quantitative criteria. This study suggests that biocontrol efficacy might vary locally depending on the frequency of less susceptible isolates and it brings to attention the possibility that selection pressure could lead to a gradual increase in the frequency of less susceptible isolates, as this biocontrol method becomes widely adopted by farmers. To our knowledge, this is the first report of the variable susceptibility of S. sclerotiorum to a commercialized strain of $P$. minitans and the first detailed characterization of a large group of isolates from France for traits related to fitness, such as mycelial growth and production of sclerotia. 


\section{Introduction}

The ascomycete Sclerotinia sclerotiorum has a broad host range and constitutes a threat to a variety of economically important crops, including oilseed rape, sunflower, soybean, and many vegetables (Bolton et al. 2006). The pathogen does not produce asexual conidia, but it can generate large numbers of sclerotia on diseased plants. These resting structures allow its long term survival and contribute to its dissemination (Coley-Smith and Cooke 1971). Under conducive conditions they germinate and produce either mycelium (myceliogenic germination), which can play a role in epidemics on certain crops, or apothecia (carpogenic germination) that may release large numbers of ascospores that are dispersed by air currents and are highly infective on most aerial plant parts (Clarkson et al. 2003; Bolton et al. 2006). Disease management in many crops is focused on the protection of the aerial plant parts against infection by ascospores, but due to their importance in the disease cycles, sclerotia are also a target for a variety of control methods (Kora et al. 2008; Derbyshire and Denton-Giles 2016; Clarkson et al. 2014; Shrestha et al. 2016; Lehner et al. 2017; Willbur et al. 2018).

The potential of using biocontrol agents to reduce soilborne populations of sclerotia or suppress their germination capacity has long been recognized (Campbell 1947; Steadman 1979; Adams 1990). Microorganisms reported to colonize sclerotia and show antagonistic properties against species of Sclerotinia include bacteria, predominantly in the genus Bacillus (Adams and Ayers 1979; Duncan et al. 2006; Chitrampalam et al. 2008; Wu et al. 2008; Zeng et al. 2012b; Gao et al. 2014; Kamal et al. 2015). However, much research has been focused on species of mycoparasitic fungi, including Coniothirium minitans (Whipps and Budge 1990), Clonostachys rosea (Rabeendran et al. 2006), Dictyosporium elegans (McCredie and Sivasithamparam 1985), several species of Gliocladium and Trichoderma (McCredie and Sivasithamparam 1985; Whipps and Budge 1990; Budge et al. 1995; Huang and Erickson 2000; Carpenter et al. 2005; Rabeendran et al. 2006; Chitrampalam et al. 2008; Geraldine et al. 2013), Paecilomyces lilacinus 
(Whipps and Budge 1990), Talaromyces flavus (McLaren et al. 1996; Huang and Erickson 2000) and Trichothetium roseum (Huang and Erickson 2000). Among those, the widely distributed fungus $C$. minitans has received much attention world-wide and various isolates of this species have shown high biocontrol potential in laboratory or in field conditions (Trutmann et al. 1980; Sandys-Winsch et al. 1993; Gerlagh et al. 1999; Huang and Erickson 2000; Budge and Whipps 2001; Jones et al. 2003; Rabeendran et al. 2006; Chitrampalam et al. 2010; Yang et al. 2011; Zeng et al. 2012b). The taxonomy of this fungus was reexamined in recent years, leading to its assignment first to the species Paraconiothyrium minitans (W.A. Campb.) Verkley, and finally to Paraphaeosphaeria minitans (W.A. Campb.) Verkley, Göker \& Stielow, comb. nov. (Verkley et al. 2014), which is the one adopted in our study.

One strain (CON/M 91-08) of P. minitans has been developed into a commercial product (De Vrije et al. 2001) and is now deployed in many countries. Field studies with the commercial product have shown successful reduction in the density of soilborne sclerotia for different species of Sclerotinia and disease suppression on various crops (von Tiedemann et al. 2001; Partridge et al. 2006; Chitrampalam et al. 2008; Öhberg and Bång 2010; Zeng et al. 2012a; Elsheshtawi et al. 2017). Variable results have also been reported in certain cases (Jones et al. 2004; Chitrampalam et al. 2010; Van Beneden et al. 2010; Bitsadze et al. 2015). In France, P. minitans has been increasingly used against $S$. sclerotiorum on various arable and vegetable crops since the first registration of the commercial product Contans ${ }^{\circledR}$ in 2001 . Feedback from farmers are largely positive, but also suggest possible regional differences in efficacy, with a tendency for better control levels reported in the North than in the South of the country in open field conditions.

A wide range of abiotic and biotic factors may influence the efficacy of biocontrol and logically, variability in field efficacy of biocontrol is often attributed to environmental variability (Nicot et al. 2011). A seldom-considered hypothesis could also be that some 
variability in biocontrol efficacy might result from differences in the susceptibility to biological control agents among the naturally occurring populations of the pathogens. A few reports have pointed to the possibility that plant pathogens could possess or develop reduced susceptibility to biocontrol agents (Bardin et al. 2015). Although information is lacking about the strain of P. minitans used in the commercial product Contans ${ }^{\circledR}$, variability was reported for the pathogenicity of two $P$. minitans strains from the UK to different isolates of $S$. sclerotiorum and S. trifoliorum (Turner and Tribe 1976). In this study sclerotia were inoculated, placed at the surface of wet sand in trays and incubated for several weeks in humid conditions. The sclerotia were then periodically assessed visually for symptoms of infection by $P$. minitans and the numbers of symptom-showing sclerotia were recorded. Interestingly, the authors also observed the development of fungus gnat larvae on some of the sclerotia, and the possible role of these insects in the biocontrol of S. sclerotiorum was later formally investigated (Anas and Reeleder 1988; Gracia-Garza et al. 1997). Although the infection study of Turner and Tribe did not allow for statistical analyses, and the experimental conditions did not exclude a possible interference of different biotic factors with mycoparasitism, their results suggest that intrinsic differences in susceptibility to P. minitans may exist among isolates of S. sclerotiorum.

In order to better understand the regional differences in the field efficacy of biocontrol against S. sclerotiorum in France, the objectives our study were (i) to evaluate and quantify the variability in susceptibility to $P$. minitans among a large sample of $S$. sclerotiorum isolates collected from different regions of France and (ii) to test the hypothesis that isolates in the North may be more susceptible than those in the South of France. For this, we used a standardized quantitative in vitro assay developed in preliminary study to assess the susceptibility of $S$. sclerotiorum to P. minitans under axenic conditions (Nicot et al. 2016).

\section{Materials and Methods}




\section{Isolates of $S$. sclerotiorum and production of sclerotia.}

A total of 75 isolates of S. sclerotiorum were used in the present study. They belong to a core collection of isolates characterized for their genetic diversity in earlier work (Leyronas et al. 2018). They originated from sclerotia collected on diseased plants in commercial fields from several regions of France (Table 1). Upon reception in our laboratory the sclerotia were systematically surface-disinfested with $5 \%$ sodium hypochlorite (three minutes, followed with three rinses in sterile water), plated on Potato Dextrose Agar medium (PDA) and incubated in a growth chamber at $21^{\circ} \mathrm{C}$ under fluorescent light $\left(162 \mu \mathrm{mol} \mathrm{s} \mathrm{s}^{-1} \mathrm{~m}^{-2} ; 10\right.$ hour photoperiod) to stimulate myceliogenic germination. The resulting colonies were subjected to single-hyphal tip isolation as described by Lehner et al. (2016). The isolates were then stored at $-20^{\circ} \mathrm{C}$.

Prior to a test with $P$. minitans fresh sclerotia were produced for each isolate in $90-\mathrm{mm}$ diameter Petri plates containing $17 \mathrm{~mL}$ of PDA. The plates were incubated for three weeks in a growth chamber at $21^{\circ} \mathrm{C}$ under fluorescent light $\left(162 \mu \mathrm{mol} \mathrm{s}^{-1} \mathrm{~m}^{-2} ; 10\right.$-hour photoperiod). The sclerotia were then collected and used immediately as described below.

\section{Inoculum of $P$. minitans and inoculation of $S$. sclerotiorum sclerotia}

One strain of $P$. minitans was used throughout this study. It was isolated by dilution plating from a preparation of the commercial product Contans ${ }^{\circledR}$. The isolate was then monospored as described for $B$. cinerea (Leyronas et al. 2012) and stored as a concentrated spore suspension $\left(10^{8}\right.$ spores $\left.\mathrm{mL}^{-1}\right)$ at $-20^{\circ} \mathrm{C}$ in $20 \%$ glycerol until use. Fresh inoculum was

produced for each test with $S$. sclerotiorum by depositing $2 \mu \mathrm{L}$ aliquots of stored spore suspension in the center of Petri plates containing PDA. The plates were incubated at $21^{\circ} \mathrm{C}$ under fluorescent light as described above. After three weeks, spores were collected from the colonies in sterile water and filtered aseptically through $30-\mu \mathrm{m}$ mesh sterile filters to remove 
mycelial fragments. The final inoculum of $P$. minitans consisted of spore suspensions adjusted to a concentration of $10^{8}$ spores $\mathrm{mL}^{-1}$.

For each isolate of $S$. sclerotiorum, four batches of 20 sclerotia were prepared in sterile tubes and mixed with $2 \mathrm{~mL}$ of either $P$. minitans inoculum (three inoculated batches) or sterile water (one control batch). Each batch of sclerotia was then mixed into $150 \mathrm{~g}$ of sterile sand in a $180 \mathrm{~mL}$ sample jar and incubated in the dark at $21^{\circ} \mathrm{C}$.

\section{Quantifying the effect of $P$. minitans on sclerotia of $S$. sclerotiorum}

After three weeks of incubation, the sclerotia were recovered from the sand and disinfested in 5\% sodium hypochlorite (for three minutes, followed by three rinses in sterile water) to remove $P$. minitans from their surface. Each sclerotium was then cut in half and the two fragments were plated on PDA, with the cut surface against the medium to facilitate the growth of $S$. sclerotiorum and $P$. minitans from the medulla of the sclerotia. For each isolate of S. sclerotiorum, a total of 80 half-sclerotia were plated on PDA, 60 from the batches of inoculated sclerotia and 20 from non-inoculated control sclerotia. All plates were incubated for one week at $21^{\circ} \mathrm{C}$ under fluorescent light as described above.

To assess the impact of internal colonization of sclerotia by $P$. minitans and quantify the susceptibility of $S$. sclerotiorum, the growth of P. minitans and of S. sclerotium from each half sclerotium was recorded after three and seven days of incubation. The number of daughter sclerotia produced by $S$. sclerotiorum on the Petri plates after seven days of incubation was also recorded.

To account for possible underlying differences in mycelial growth rates among isolates of S. sclerotiorum, a relative index was computed to compare their development from inoculated and non-inoculated sclerotia and thus quantify a reduction that would result 
specifically from the effect of $P$. minitans. This index of reduction of mycelial growth was computed as:

$$
\mathrm{IRm}=100 *\left(\mathrm{D}_{\text {control }}-\mathrm{D}_{\text {inoculated }}\right) / \mathrm{D}_{\text {control }}
$$

where $\mathrm{D}_{\text {inoculated }}$ was the diameter of the S. sclerotiorum colonies on PDA after 3 days of incubation of sclerotia inoculated with $P$. minitans and $\mathrm{D}_{\text {control was that for non-inoculated }}$ control sclerotia. Similarly, an index of reduction of the production of daughter sclerotia by $S$. sclerotiorum was computed as:

$$
\text { IRs }=100 *\left(\mathrm{~N}_{\text {control }}-\mathrm{N}_{\text {inoculated }}\right) / \mathrm{N}_{\text {control }},
$$

where $\mathrm{N}_{\text {inoculated }}$ was the number of daughter sclerotia produced on PDA after 7 days of incubation of sclerotia inoculated with $P$. minitans and $\mathrm{N}_{\text {control }}$ was that for non-inoculated control sclerotia.

\section{Statistical analyses}

All statistical analyses were carried out with Statistica (Dell). The "Non-parametric Tests" module (Kruskal-Wallis tests) was used to evaluate differences of susceptibility to $P$. minitans among isolates of $S$. sclerotiorum as characterized by the different criteria described above. Wilcoxon-Mann-Whitney tests were used to evaluate the specific effect of $P$. minitans on each individual isolate by comparing colony diameter and production of daughter sclerotia from sclerotia of $S$. sclerotiorum previously incubated with the mycoparasite and from control non-inoculated sclerotia. These tests were also used to compare the susceptibility of the group of $S$. sclerotiorum isolates from the North to that of isolates from the South of France.

Finally, polynomial regression analyses were implemented with the "General Linear Model" module to examine possible relations between the various criteria used to characterize the susceptibility of the 75 isolates of S. sclerotiorum. 


\section{Results}

\section{Growth of $P$. minitans from sclerotia of $S$. sclerotiorum}

Development of $P$. minitans colonies on PDA was never observed from non-inoculated sclerotia of $S$. sclerotiorum. Colonies of $P$. minitans developed from many but not all inoculated sclerotia, suggesting that for some of them, the extent of internal colonization by the mycoparasite was not sufficient to allow detectable growth within 7 days after the half-sclerotia were deposited on PDA. The frequency of detection of growth of $P$. minitans from sclerotia (Figure 1) differed significantly between isolates of $S$. sclerotiorum $(P=0.002)$ despite substantial variability among the three independent batches of sclerotia examined for each isolate, as shown by the size of the error bars. Similarly, the extent of $P$. minitans mycelial growth (Figure 2) from the colonies differed significantly between isolates of $S$. sclerotiorum $(P<0.001)$, with a much smaller level of variability among the 60 half sclerotia examined for each isolate. Polynomial regression analysis showed that these two types of assessment of the extent of sclerotial colonization by $P$. minitans were significantly associated (Figure 3), with the best fit obtained as $y=0.0024 x^{2}+0.0188 x+0.9284\left(\mathrm{R}^{2}=0.8435 ; P<0.001\right)$, where $y$ was the colony diameter (in $\mathrm{mm}$ ) and $x$ the frequency of detection (in $\%$ ) of $P$. minitans from $S$. sclerotiorum sclerotia.

For both of these criteria used to assess the susceptibility of $S$. sclerotiorum to $P$. minitans, there was no significant difference between the group of isolates from the North and those from the South of France (Table 2).

\section{Mycelial growth of S. sclerotiorum from sclerotia}

Mycelial growth of $S$. sclerotiorum on PDA medium was observed for all noninoculated sclerotia and for many but not all sclerotia previously incubated for three weeks with P. minitans in sterile sand. For 29 of the 75 isolates examined, mycelial development occurred 
from $100 \%$ of the inoculated sclerotia, while for the other isolates, mycelial growth was absent for up to $80 \%$ of the sclerotia (Figure 4), suggesting that the mycoparasite had compromised their viability. There was no significant difference between isolates from the North and from the South of France (Table 2). Based on polynomial regression analyses, the likelihood for the sclerotia of an isolate to show no mycelial germination was significantly related (Figure 5), both to the observed frequency of development of $P$. minitans on PDA medium from those sclerotia $\left(Y=0.0085 x^{2}-0.4447 x+5.4202 ; \mathrm{R}^{2}=0.5547, P<0.001\right)$ and to the diameter of resulting $P$. minitans colonies $\left(Y=0.0561 x^{2}+0.2479 x-0.052 ; \mathrm{R}^{2}=0.8054, P<0.001\right)$.

The diameter of S. sclerotiorum colonies three days after the plating of sclerotia on PDA medium varied widely among isolates, both for non-inoculated sclerotia and for those previously incubated for three weeks with $P$. minitans in sterile sand (data not shown; $P<0.001$ for both). The IRm index, computed to assess the reduction of mycelial growth from inoculated sclerotia relative to non-inoculated control sclerotia also varied significantly among isolates $(P$ $<0.001$, Figure 6). For 46 of the 75 S. sclerotiorum isolates, IRm had a positive value, reflecting the fact that colony diameter from inoculated sclerotia was lower than that for control non-inoculated sclerotia, with statistically significant differences for 17 of those isolates $(\mathrm{P}<$ 0.05; Wilcoxon-Mann-Whitney test). However, IRm had negative values for 29 isolates, for which the diameter of the $S$. sclerotiorum colony was greater for sclerotia inoculated with $P$. minitans than for control non-inoculated sclerotia (Figure 6). For those isolates, the mycoparasite appeared to have stimulated, rather than inhibited, mycelial germination and subsequent growth of S. sclerotiorum on PDA medium. The differences were statistically significant for 19 of those isolates $(P<0.05$; Wilcoxon-Mann-Whitney test). There was no significant difference between isolates from the North and from the South of France (Table 2). Polynomial regression analyses showed statistically significant relations $(P<0.05)$ between the Index of Reduction of mycelial growth and several predictors such as the frequency of 
development of $P$. minitans from sclerotia $\left(y=0.0043 x^{2}+0.3403 x-29.144 ; \mathrm{R}^{2}=0.421 ;\right.$ Figure 7-A), the diameter of resulting $P$. minitans colonies $\left(y=-0.0239 x^{2}+3.6866 x-31.056 ; \mathrm{R}^{2}=\right.$ 0.542; Figure 7-B). In contrast, the diameter of S. sclerotiorum colonies growing from control non-inoculated sclerotia was a poor predictor of $\operatorname{IRm}\left(R^{2}=0.094\right.$; Figure 7-C).

\section{Production of daughter sclerotia by $S$. sclerotiorum}

The index IRs, computed to assess the reduction in production of daughter sclerotia by colonies growing from inoculated sclerotia relative to non-inoculated control sclerotia varied significantly among isolates $(P<0.001$, Figure 8$)$. For 49 of the 75 . sclerotiorum isolates, IRs had a positive value, reflecting the fact that production of daughter sclerotia on colonies from inoculated sclerotia was lower than that for control non-inoculated sclerotia. IRs also showed negative values for some of the isolates, for which the production of daughter sclerotia by the $S$. sclerotiorum colonies growing from sclerotia inoculated with $P$. minitans was enhanced compared to control non-inoculated sclerotia (Figure 8). There was no significant difference between isolates from the North and from the South of France (Table 2).

Polynomial regression analyses showed statistically significant relationship $(P<0.05)$ between the Index of reduction of production of daughter sclerotia and several predictors such as the frequency of development of $P$. minitans from sclerotia $\left(y=0.0056 x^{2}+0.0932 x-8.9736 ; \mathbf{R}^{2}=0.331\right)$, the diameter of resulting $P$. minitans colonies $\left(y=-0.0295 x^{2}+2.278 x-12.353 ; \mathbf{R}^{2}=0.580\right)$. In contrast, colony diameter and the production of daughter sclerotia by $S$. sclerotiorum colonies growing from control non-inoculated sclerotia were poor predictors of IRs ( $\mathrm{R}^{2}$ of 0.031 and 0.002 , respectively; $P>0.05$ for both predictors).

\section{Discussion}


Using a standardized assay in controlled axenic conditions, the present study showed wide differences in susceptibility to $P$. minitans among 75 isolates of $S$. sclerotiorum, with consistent responses for four criteria used to assess the impact of the mycoparasite. To our knowledge, this is the first study documenting the diversity in susceptibility of S. sclerotiorum to a commercialized strain of $P$. minitans and the first detailed characterization of a large group of isolates from France for traits related to fitness, such as mycelial growth and production of sclerotia.

A similarly high level of diversity was found among isolates collected from the North or from the South of France, and no significant regional difference was observed, suggesting that other hypotheses should be considered to explain the reported tendency for better field efficacy of biocontrol in the North. Many environmental factors, both abiotic and biotic, are known to influence the survival of sclerotia in soil (Bell et al. 1998; Duncan et al. 2006; Wu et al. 2008; Ćosić et al. 2012). Natural predation of sclerotia by various soil invertebrate species as well as degradation by soilborne microorganisms have been documented (Coley-Smith and Cooke 1971; Anas 1987; Gracia-Garza et al. 1997). Strains of P. minitans naturally present in soil, even if their density is likely to be considerably lower than that of the commercial biocontrol strain after soil treatments (Zeng et al. 2012b), could also play a role. Many environmental factors may also influence the biology and mycoparasitic activity of $P$. minitans, and differences in farming practices, including for field application of the biocontrol product, could thus lead to contrasted efficacy of the treatments (De Vrije et al. 2001; Partridge et al. 2006; Jones et al. 2011; Yang et al. 2011).

To avoid possible interference with some of these factors and focus on investigating intrinsic differences in susceptibility among isolates of $S$. sclerotiorum, the in vitro assay developed for the present study was highly standardized and the mycoparasitic activity of $P$. minitans on the sclerotia was limited to a three-week incubation period. Therefore, our 
observations are unlikely to represent fully the behavior of the $S$. sclerotiorum isolates in a field situation. For example, sclerotia found free of infection by $P$. minitans after a three-week incubation period might eventually become parasitized over a longer time lap. Furthermore, in field conditions the numerous possible interfering factors evoked above might not affect identically the outcome of mycoparasitism for all isolates of S. sclerotiorum. Much additional research is needed to understand the mechanisms responsible for the differences of susceptibility revealed in our study and how those mechanisms could be affected by various factors operating in the field.

Even in a simplified experimental context as in the present study, our results highlight that mycoparasitism is clearly the complex outcome of multiple phenomena which occurred both during the three-week incubation period of sclerotia in the sample jars and after the sclerotia were plated on the PDA medium. This is exemplified by the unexpected negative values of the indices IRm (Figure 6) observed for certain isolates. Our starting hypothesis was that the extent of mycoparasitism in a sclerotium would lead to correspondingly reduced biomass of S. sclerotiorum, and that this in turn would result in slower germination and less vigorous mycelial growth from inoculated, compared to non-inoculated sclerotia. Things were clearly more complex. Although regression analysis showed that IRm was significantly related to other criteria used to characterize the susceptibility of $S$. sclerotiorum isolates, mycelial growth from inoculated sclerotia of the least susceptible isolates was stimulated (rather than showing reduced inhibition) relative to control non-inoculated sclerotia. Among possible explanations, one could be that two opposite phenomena occurred simultaneously, causing the observed outcome for these least susceptible isolates: (i) the penetration of the hard, melanized cortex of the sclerotia may have been slower or reduced, thus leading to reduced parasitism of the medullar part, and (ii) simultaneously the partial degradation of the cortex may be a stimulating factor for sclerotial germination, facilitating quicker growth of mycelium out of the 
sclerotia when they were plated on PDA. Further work will be needed to test formally this and possibly other hypotheses. The same hypotheses may be examined to explain the negative IRs values (Figure 8), as sclerotial production by S. sclerotiorum on agar media is mostly initiated when the growing margin of a mycelial colony reaches the rim of the Petri plate. In addition to a possible link between production of daughter sclerotia and the kinetics of mycelial growth on PDA medium, a role of mycoparasitism on mycelia of $S$. sclerotiorum may also need to be further examined, as it is known to occur in vitro (Huang et al. 2011) as well as in planta (Trutmann et al. 1982), with possible consequences for production of daughter sclerotia in the latter case.

In conclusion, regardless of the possible mechanisms involved, the findings of the present study constitute a clear documentation of differences in susceptibility to a biocontrol agent among isolates of a plant pathogen, adding a contribution to a still very limited knowledge (Bardin et al. 2015). Differences in susceptibility of $S$. sclerotiorum to P. minitans cannot explain differences in the efficacy of Contans ${ }^{\circledR}$ in the North and the South of France. Nevertheless, the wide range of variability observed among isolates of S. sclerotiorum, regardless of their geographic origin, suggests that biocontrol efficacy might vary locally depending on the frequency of less susceptible isolates in specific fields. These results also bring to attention the possibility that selection pressure could lead to a gradual increase in the frequency of less susceptible isolates of the pathogen, as this biocontrol method becomes widely adopted by farmers.

\section{Acknowledgements}

This work was supported in part by funding from the European Union's Horizon 2020 research and innovation programme under grant agreement $\mathrm{N}^{\circ} 633184$ ("EUCLID" project) and by a CASDAR grant from the French Ministry of Agriculture together with the Scientific Interest 
Group "GIS PICLég" ("ScleroLeg" project). The authors thank all the field experimenters of the French technical institutes (CTIFL, ACPEL, APEF, CEFEL, Invenio, SILEBAN, Terres Inovia UNILET) who collaborated in the project and who collected the isolates used in the present study.

\section{References}

Adams P, Ayers W (1979) Ecology of Sclerotinia species. Phytopathology 69 (8):896-899

Adams PB (1990) The potential of mycoparasites for biological control of plant diseases. Annual Review of Phytopathology 28 (1):59-72.

Anas O (1987) Recovery of fungi and arthropods from sclerotia of Sclerotinia sclerotiorum in Quebec muck soils. Phytopathology 77:327-331

Anas O, Reeleder R (1988) Consumption of sclerotia of Sclerotinia sclerotiorum by larvae of Bradysia coprophila: influence of soil factors and interactions between larvae and Trichoderma viride. Soil Biology and Biochemistry 20 (5):619-624

Bardin M, Ajouz S, Comby M, Lopez-Ferber M, Graillot B, Siegwart M, Nicot PC (2015) Is the efficacy of biological control against plant diseases likely to be more durable than that of chemical pesticides? Frontiers in Plant Science 6 (566). doi:10.3389/fpls.2015.00566

Bell AA, Liu L, Reidy B, Davis RM, Subbarao KV (1998) Mechanisms of subsurface drip irrigation-mediated suppression of lettuce drop caused by Sclerotinia minor. Phytopathology 88 (3):252-259

Bitsadze N, Siebold M, Koopmann B, von Tiedemann A (2015) Single and combined colonization of Sclerotinia sclerotiorum sclerotia by the fungal mycoparasites Coniothyrium minitans and Microsphaeropsis ochracea. Plant Pathology 64 (3):690-700

Bolton MD, Thomma BPHJ, Nelson BD (2006) Sclerotinia sclerotiorum (Lib.) de Bary: biology and molecular traits of a cosmopolitan pathogen. Molecular Plant Pathology 7 (1):1-16

Budge SP, McQuilken MP, Fenlon JS, Whipps JM (1995) Use of Coniothyrium minitans and Gliocladium virens for biological control of Sclerotinia sclerotiorum in glasshouse lettuce. Biological Control 5 (4):513-522

Budge SP, Whipps JM (2001) Potential for integrated control of Sclerotinia sclerotiorum in glasshouse lettuce using Coniothyrium minitans and reduced fungicide application. Phytopathology 91 (2):221-227

Campbell W (1947) A new species of Coniothyrium parasitic on sclerotia. Mycologia 39 (2):190-195 
Carpenter MA, Stewart A, Ridgway HJ (2005) Identification of novel Trichoderma hamatum genes expressed during mycoparasitism using subtractive hybridisation. FEMS Microbiology Letters 251 (1):105-112

Chitrampalam P, Cox CA, Turini TA, Pryor BM (2010) Efficacy of Coniothyrium minitans on lettuce drop caused by Sclerotinia minor in desert agroecosystem. Biological Control 55 (2):92-96

Chitrampalam P, Figuli P, Matheron M, Subbarao K, Pryor BM (2008) Biocontrol of lettuce drop caused by Sclerotinia sclerotiorum and S. minor in desert agroecosystems. Plant Disease 92 (12):1625-1634

Clarkson JP, Fawcett L, Anthony SG, Young C (2014) A model for Sclerotinia sclerotiorum infection and disease development in lettuce, based on the effects of temperature, relative humidity and ascospore density. PLoS One 9 (4):e94049

Clarkson JP, Staveley J, Phelps K, Young CS, Whipps JM (2003) Ascospore release and survival in Sclerotinia sclerotiorum. Mycological Research 107 (2):213-222

Coley-Smith J, Cooke R (1971) Survival and germination of fungal sclerotia. Annual Review of Phytopathology 9 (1):65-92

Ćosić J, Jurković D, Vrandečić K, Kaučić D (2012) Survival of buried Sclerotinia sclerotiorum sclerotia in undisturbed soil. Helia 35 (56):73-78

De Vrije T, Antoine N, Buitelaar R, Bruckner S, Dissevelt M, Durand A, Gerlagh M, Jones E, Lüth P, Oostra J (2001) The fungal biocontrol agent Coniothyrium minitans: production by solid-state fermentation, application and marketing. Applied microbiology and biotechnology 56 (1-2):58-68

Derbyshire MC, Denton-Giles M (2016) The control of sclerotinia stem rot on oilseed rape (Brassica napus): current practices and future opportunities. Plant Pathology 65 (6):859877

Duncan RW, Dilantha Fernando WG, Rashid KY (2006) Time and burial depth influencing the viability and bacterial colonization of sclerotia of Sclerotinia sclerotiorum. Soil Biology and Biochemistry 38 (2):275-284

Elsheshtawi M, Elkhaky MT, Sayed SR, Bahkali AH, Mohammed AA, Gambhir D, Mansour AS, Elgorban AM (2017) Integrated control of white rot disease on beans caused by Sclerotinia sclerotiorum using Contans ${ }^{\circledR}$ and reduced fungicides application. Saudi Journal of Biological Sciences 24 (2):405-409

Gao XN, Han QM, Chen YF, Qin HQ, Huang LL, Kang ZS (2014) Biological control of oilseed rape Sclerotinia stem rot by Bacillus subtilis strain Em7. Biocontrol Science and Technology 24 (1):39-52

Geraldine AM, Lopes FAC, Carvalho DDC, Barbosa ET, Rodrigues AR, Brandão RS, Ulhoa CJ, Lobo Junior M (2013) Cell wall-degrading enzymes and parasitism of sclerotia are key factors on field biocontrol of white mold by Trichoderma spp. Biological Control 67 (3):308-316 
Gerlagh M, Goossen-van de Geijn HM, Fokkema NJ, Vereijken PFG (1999) Long-term biosanitation by application of Coniothyrium minitans on Sclerotinia sclerotiorum-infected crops. Phytopathology 89 (2):141-147

Gracia-Garza JA, Reeleder RD, Paulitz TC (1997) Degradation of sclerotia of Sclerotinia sclerotiorum by fungus gnats (Bradysia coprophila) and the biocontrol fungi Trichoderma spp. Soil Biology and Biochemistry 29 (2):123-129

Huang HC, Erickson RS (2000) Soil treatment with fungal agents for control of apothecia of Sclerotinia sclerotiorum in bean and pea crops. Plant Pathology Bulletin 9 (2):53-58

Huang Y, Xie X, Yang L, Zhang J, Li G, Jiang D (2011) Susceptibility of Sclerotinia sclerotiorum strains different in oxalate production to infection by the mycoparasite Coniothyrium minitans. World Journal of Microbiology and Biotechnology 27 (12):27992805

Jones E, Mead A, Whipps J (2003) Evaluation of different Coniothyrium minitans inoculum sources and application rates on apothecial production and infection of Sclerotinia sclerotiorum sclerotia. Soil Biology and Biochemistry 35 (3):409-419

Jones E, Mead A, Whipps J (2004) Effect of inoculum type and timing of application of Coniothyrium minitans on Sclerotinia sclerotiorum: control of sclerotinia disease in glasshouse lettuce. Plant Pathology 53 (5):611-620

Jones EE, Stewart A, Whipps JM (2011) Water potential affects Coniothyrium minitans growth, germination and parasitism of Sclerotinia sclerotiorum sclerotia. Fungal Biology 115 (9):871-881

Kamal MM, Lindbeck KD, Savocchia S, Ash GJ (2015) Biological control of sclerotinia stem rot of canola using antagonistic bacteria. Plant Pathology 64 (6):1375-1384

Kora C, McDonald MR, Boland GJ (2008) New progress in the integrated management of sclerotinia rot of carrot. In: Ciancio A, Mukerji KG (eds) Integrated Management of Diseases Caused by Fungi, Phytoplasma and Bacteria. Springer Netherlands, Dordrecht, pp 243-270

Lehner MS, Del Ponte EM, Gugino BK, Kikkert JR, Pethybridge SJ (2017) Sensitivity and efficacy of boscalid, fluazinam, and thiophanate-methyl for white mold control in snap bean in New York. Plant Dis 101 (7):1253-1258. doi:10.1094/PDIS-12-16-1731-RE

Lehner MS, Lima RC, Carneiro JES, Paula TJ, Vieira RF, Mizubuti ESG (2016) Similar aggressiveness of phenotypically and genotypically distinct isolates of Sclerotinia sclerotiorum. Plant Dis 100 (2):360-366

Leyronas C, Duffaud M, Nicot PC (2012) Compared efficiency of the isolation methods for Botrytis cinerea. Mycology: An International Journal on Fungal Biology 3 (4):221-225

Leyronas C, Troulet C, Duffaud M, Villeneuve F, Benigni M, Leignez S, Nicot PC (2018) First report of Sclerotinia subarctica in France detected with a rapid PCR-based test. Canadian Journal of Plant Pathology:1-6. doi:10.1080/07060661.2018.1438515 
McCredie TA, Sivasithamparam K (1985) Fungi mycoparasitic on sclerotia of Sclerotinia sclerotiorum in some Western Australian soils. Transactions of the British Mycological Society 84 (4):736-739

McLaren D, Huang H, Rimmer S (1996) Control of apothecial production of Sclerotinia sclerotiorum by Coniothyrium minitans and Talaromyces flavus. Plant disease 80 (12): 1373-1378

Nicot P, Bardin M, Alabouvette C, Köhl J (2011) Potential of biological control based on published research. 1. Protection against plant pathogens of selected crops. In: Nicot P (ed) Classical and augmentative biological control against diseases and pests: critical status analysis and review of factors influencing their success. IOBC/WPRS, Zürich, Switzerland, pp 1-11

Nicot PC, Avril F, Duffaud M, Leyronas C, Troulet C, Villeneuve F, Bardin M (2016) Are there regional differences in the susceptibility of Sclerotinia sclerotiorum strains to Coniothyrium minitans? IOBC WPRS Bulletin 117:83-87

Öhberg H, Bång U (2010) Biological control of clover rot on red clover by Coniothyrium minitans under natural and controlled climatic conditions. Biocontrol Science and Technology 20 (1):25-36

Partridge DE, Sutton TB, Jordan DL (2006) Effect of environmental factors and pesticides on mycoparasitism of Sclerotinia minor by Coniothyrium minitans. Plant Disease 90 (11):1407-1412

Rabeendran N, Jones EE, Moot DJ, Stewart A (2006) Biocontrol of Sclerotinia lettuce drop by Coniothyrium minitans and Trichoderma hamatum. Biological Control 39 (3):352-362

Sandys-Winsch C, Whipps JM, Gerlagh M, Kruse M (1993) World distribution of the sclerotial mycoparasite Coniothyrium minitans. Mycological Research 97 (10):1175-1178

Shrestha U, Augé RM, Butler DM (2016) A meta-analysis of the impact of anaerobic soil disinfestation on pest suppression and yield of horticultural crops. Frontiers in Plant Science 7:1254. doi:10.3389/fpls.2016.01254

Steadman J (1979) Control of plant diseases caused by Sclerotinia species. Phytopathology 69 (8):904-907

Trutmann P, Keane PJ, Merriman PR (1980) Reduction of sclerotial inoculum of Sclerotinia sclerotiorum with Coniothyrium minitans. Soil Biology and Biochemistry 12 (5):461-465

Trutmann P, Keane PJ, Merriman PR (1982) Biological control of Sclerotinia sclerotiorum on aerial parts of plants by the hyperparasite Coniothyrium minitans. Transactions of the British Mycological Society 78 (3):521-529

Turner GJ, Tribe HT (1976) On Coniothyrium minitans and its parasitism of Sclerotinia species. Transactions of the British Mycological Society 66 (1):97-105

Van Beneden S, Leenknegt I, França SC, Höfte M (2010) Improved control of lettuce drop caused by Sclerotinia sclerotiorum using Contans combined with lignin or a reduced fungicide application. Crop Protection 29 (2):168-174 
Verkley GJM, Dukik K, Renfurm R, Göker M, Stielow JB (2014) Novel genera and species of coniothyrium-like fungi in Montagnulaceae (Ascomycota). Persoonia : Molecular Phylogeny and Evolution of Fungi 32:25-51

von Tiedemann A, Hedke K, Mögling R (2001) Abbauverhalten von Sklerotien der Weißstängeligkeit bei Einsatz von Contans. Raps 1:1-3

Whipps JM, Budge SP (1990) Screening for sclerotial mycoparasites of Sclerotinia sclerotiorum. Mycological Research 94 (5):607-612

Willbur JF, Fall ML, Bloomingdale C, Byrne AM, Chapman SA, Isard SA, Magarey RD, McCaghey MM, Mueller BD, Russo JM, Schlegel J, Chilvers MI, Mueller DS, Kabbage M, Smith DL (2018) Weather-based models for assessing the risk of Sclerotinia sclerotiorum apothecial presence in soybean (Glycine max) fields. Plant Dis 102 (1):73-84

Wu BM, Subbarao KV, Liu YB (2008) Comparative survival of sclerotia of Sclerotinia minor and S. sclerotiorum. Phytopathology 98 (6):659-665

Yang L, Li G, Zhang J, Jiang D, Chen W (2011) Compatibility of Coniothyrium minitans with compound fertilizer in suppression of Sclerotinia sclerotiorum. Biological Control 59 (2):221-227

Zeng W, Kirk W, Hao J (2012a) Field management of Sclerotinia stem rot of soybean using biological control agents. Biological Control 60 (2):141-147

Zeng W, Wang D, Kirk W, Hao J (2012b) Use of Coniothyrium minitans and other microorganisms for reducing Sclerotinia sclerotiorum. Biological Control 60 (2):225-232 
Table 1: Code number and origin of the 75 isolates of Sclerotinia sclerotiorum characterized in the present study.

\begin{tabular}{|c|c|c|c|c|c|c|c|c|c|}
\hline Isolate & Host & & $\begin{array}{l}\text { gion } \\
\text { trict) }{ }^{1}\end{array}$ & $\begin{array}{c}\text { Year of } \\
\text { samplin } \\
\mathrm{g}\end{array}$ & Isolate & Host & \multicolumn{2}{|c|}{$\underset{\text { (district) }^{1}}{\text { Region }}$} & Year \\
\hline 2 & Lettuce & $\mathrm{S}$ & (84) & 2012 & 83 & Melon & $\mathrm{S}$ & (17) & 2014 \\
\hline 3 & Lettuce & $\mathrm{S}$ & (84) & 2012 & 86 & Melon & $\mathrm{S}$ & (17) & 2014 \\
\hline 4 & Lettuce & $\mathrm{S}$ & (84) & 2012 & 88 & Melon & $\mathrm{S}$ & (17) & 2014 \\
\hline 5 & Lettuce & $\mathrm{S}$ & (84) & 2012 & 90 & Melon & $\mathrm{S}$ & (17) & 2014 \\
\hline 6 & Lettuce & $\mathrm{S}$ & (84) & 2013 & 93 & Melon & $\mathrm{S}$ & (17) & 2014 \\
\hline 7 & Lettuce & $\mathrm{S}$ & (66) & 2013 & 95 & Melon & $\mathrm{S}$ & (17) & 2014 \\
\hline 10 & Green bean & $\mathrm{N}$ & (29) & 2011 & 102 & Melon & $\mathrm{S}$ & (17) & 2014 \\
\hline 17 & Green bean & $\mathrm{N}$ & (29) & 2011 & 103 & Melon & $\mathrm{S}$ & (17) & 2014 \\
\hline 23 & Green bean & & (29) & 2012 & 106 & Melon & $\mathrm{S}$ & (17) & 2014 \\
\hline 24 & Green bean & $\mathrm{N}$ & (29) & 2012 & 109 & Melon & $\mathrm{S}$ & (17) & 2014 \\
\hline 25 & Green bean & $\mathrm{N}$ & (29) & 2012 & 120 & Rapeseed & $\mathrm{N}$ & (21) & 2014 \\
\hline 28 & Green bean & $\mathrm{N}$ & (29) & 2012 & 121 & Rapeseed & $\mathrm{S}$ & (47) & 2014 \\
\hline 29 & Green bean & $\mathrm{N}$ & (56) & 2012 & 123 & Rapeseed & $\mathrm{N}$ & (77) & 2014 \\
\hline 30 & Green bean & & (29) & 2012 & 125 & Rapeseed & $\mathrm{N}$ & (78) & 2014 \\
\hline 31 & Green bean & $\mathrm{N}$ & (29) & 2012 & 138 & Rapeseed & $\mathrm{N}$ & (77) & 2014 \\
\hline 33 & Green bean & & (29) & 2012 & 161 & Melon & $\mathrm{S}$ & (17) & 2014 \\
\hline 34 & Green bean & & (29) & 2012 & 162 & Melon & $\mathrm{S}$ & (17) & 2014 \\
\hline 35 & Green bean & & (29) & 2012 & 170 & Melon & $\mathrm{S}$ & (81) & 2014 \\
\hline 36 & Green bean & $\mathrm{N}$ & (29) & 2013 & 172 & Melon & $\mathrm{S}$ & (82) & 2014 \\
\hline 37 & Green bean & & (29) & 2013 & 173 & Melon & $\mathrm{S}$ & (82) & 2014 \\
\hline 40 & Green bean & $S$ & $(40)$ & 2012 & 174 & Melon & $\mathrm{S}$ & (82) & 2014 \\
\hline 41 & Green bean & & $(40)$ & 2012 & 176 & Melon & $\mathrm{S}$ & (17) & 2014 \\
\hline 45 & Melon & & (86) & 2012 & 242 & Melon & $\mathrm{S}$ & (17) & 2014 \\
\hline 46 & Rapeseed & & (57) & 2003 & 736 & $\begin{array}{l}\text { Witloof } \\
\text { chicory }\end{array}$ & $\mathrm{N}$ & (62) & 2001 \\
\hline 48 & Rapeseed & & (18) & 2007 & 739 & $\begin{array}{l}\text { Witloof } \\
\text { chicory }\end{array}$ & $\mathrm{N}$ & (62) & 2013 \\
\hline 51 & Rapeseed & & (21) & 2007 & 864 & Carrot & $\mathrm{S}$ & (33) & 2014 \\
\hline
\end{tabular}




\begin{tabular}{|c|c|cc|c|c|c|c|c|c|c|}
\hline 58 & Witloof chicory & $\mathrm{N}$ & $(60)$ & 2012 & & 866 & Carrot & $\mathrm{S}$ & $(33)$ & 2014 \\
\hline 59 & Witloof chicory & $\mathrm{N}$ & $(80)$ & 2012 & & 918 & Carrot & $\mathrm{S}$ & $(33)$ & 2014 \\
\hline 60 & Witloof chicory & $\mathrm{N}$ & $(59)$ & 2013 & & 977 & Carrot & $\mathrm{S}$ & $(33)$ & 2014 \\
\hline 61 & Witloof chicory & $\mathrm{N}$ & $(62)$ & 2012 & & 983 & Carrot & $\mathrm{S}$ & $(33)$ & 2014 \\
\hline 64 & Witloof chicory & $\mathrm{N}$ & $(62)$ & 2001 & & 1003 & Carrot & $\mathrm{S}$ & $(33)$ & 2014 \\
\hline 65 & Witloof chicory & $\mathrm{N}$ & $(80)$ & 2011 & & 1234 & Carrot & $\mathrm{S}$ & $(33)$ & 2015 \\
\hline 66 & Witloof chicory & $\mathrm{N}$ & $(59)$ & 2012 & & 1252 & Carrot & $\mathrm{S}$ & $(33)$ & 2015 \\
\hline 70 & Melon & $\mathrm{S}$ & $(17)$ & 2014 & & 1261 & Carrot & $\mathrm{S}$ & $(33)$ & 2015 \\
\hline 73 & Melon & $\mathrm{S}$ & $(82)$ & 2014 & & 1262 & Carrot & $\mathrm{S}$ & $(33)$ & 2015 \\
\hline 75 & Melon & $\mathrm{S}$ & $(82)$ & 2014 & & 1592 & Melon & $\mathrm{S}$ & $(17)$ & 2015 \\
\hline 79 & Melon & $\mathrm{S}$ & $(17)$ & 2014 & & 1869 & Melon & $\mathrm{S}$ & $(17)$ & 2015 \\
\hline
\end{tabular}

${ }^{1}$ The numbers between brackets refer to the official codes of French districts (ISO 3166; https://www.iso.org/obp/ui/\#iso:code:3166:FR), located in the northern (N) or the southern (S) part of the country 
Table 2: Differences in the susceptibility of Sclerotinia sclerotiorum isolates to $P$. minitans based on their geographic origin in the North or the South of France

\begin{tabular}{|c|c|c|c|}
\hline \multirow[t]{2}{*}{$\begin{array}{l}\text { Criteria used to estimate susceptibility to } P \text {. } \\
\text { minitans }\end{array}$} & \multicolumn{2}{|c|}{$\begin{array}{l}\text { Geographic origin of } S . \\
\text { sclerotiorum isolates }\end{array}$} & \multirow{2}{*}{$\begin{array}{l}P \quad \text { value } \\
\text { (Wilcoxon- } \\
\text { Mann } \\
\text { Whitney } \\
\text { test) }\end{array}$} \\
\hline & $\begin{array}{c}\text { North } \\
\text { (32 isolates) }\end{array}$ & $\begin{array}{c}\text { South } \\
\text { (43 isolates) }\end{array}$ & \\
\hline $\begin{array}{l}\text { Frequency of recovery of } P \text {. minitans from } \\
\text { inoculated sclerotia }(\%)\end{array}$ & 54.12 & 62.09 & 0.21 \\
\hline $\begin{array}{l}\text { Diameter of } P \text {. minitans colonies from } \\
\text { inoculated sclerotia }(\mathrm{mm})\end{array}$ & 12.27 & 12.43 & 0.86 \\
\hline $\begin{array}{l}\text { Frequency of absence of } S \text {. sclerotiorum from } \\
\text { inoculated sclerotia (\%) }\end{array}$ & 15.29 & 14.09 & 0.41 \\
\hline $\begin{array}{l}\text { Reduction of } S \text {. sclerotiorum mycelial growth } \\
\text { from inoculated sclerotia relative to non- } \\
\text { inoculated control sclerotia }(\%)\end{array}$ & 9.91 & 2.47 & 0.32 \\
\hline $\begin{array}{l}\text { Reduction in production of daughter sclerotia by } \\
\text { colonies growing from inoculated sclerotia } \\
\text { relative to non-inoculated control sclerotia }(\%)\end{array}$ & 24.31 & 18.04 & 0.51 \\
\hline
\end{tabular}




\section{Figures}

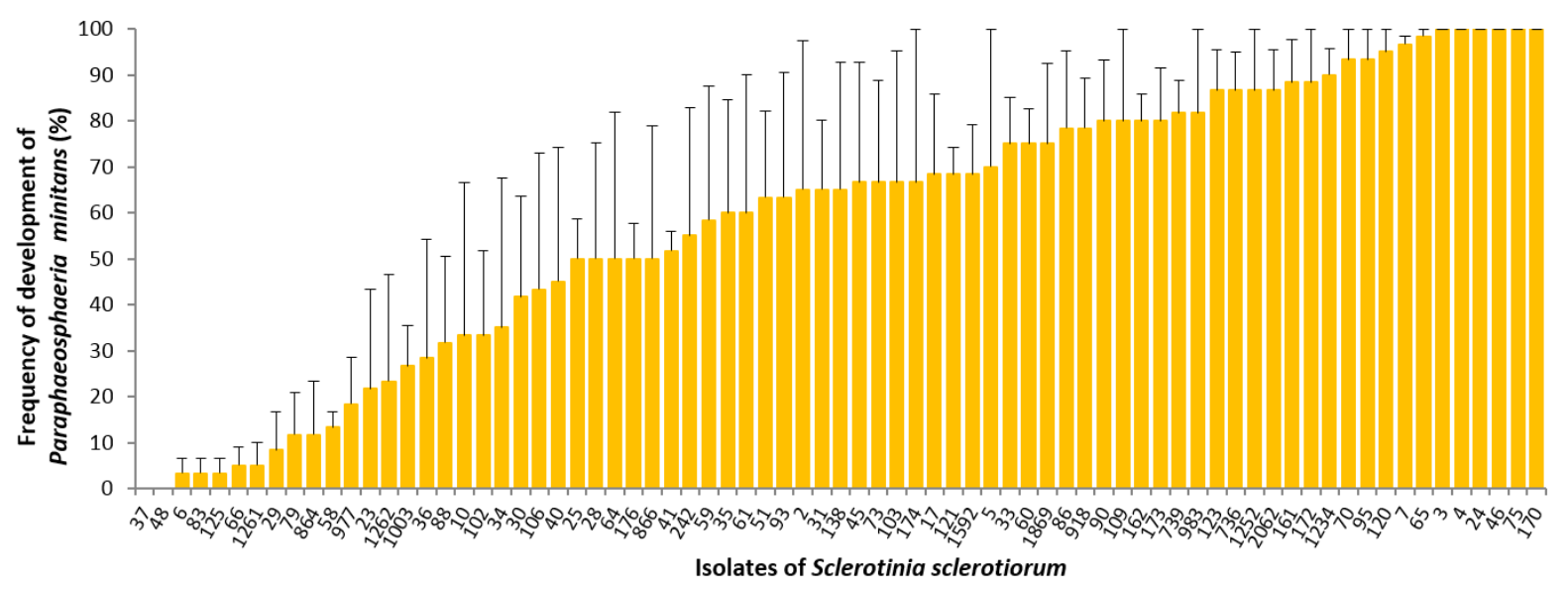

Figure 1: Frequency of development of Paraphaeosphaeria minitans from inoculated sclerotia of 75 Sclerotinia sclerotiorum isolates incubated for seven days on PDA medium. For each isolate, the data represent averages for three replicate batches of 20 half sclerotia \pm standard error of the mean.

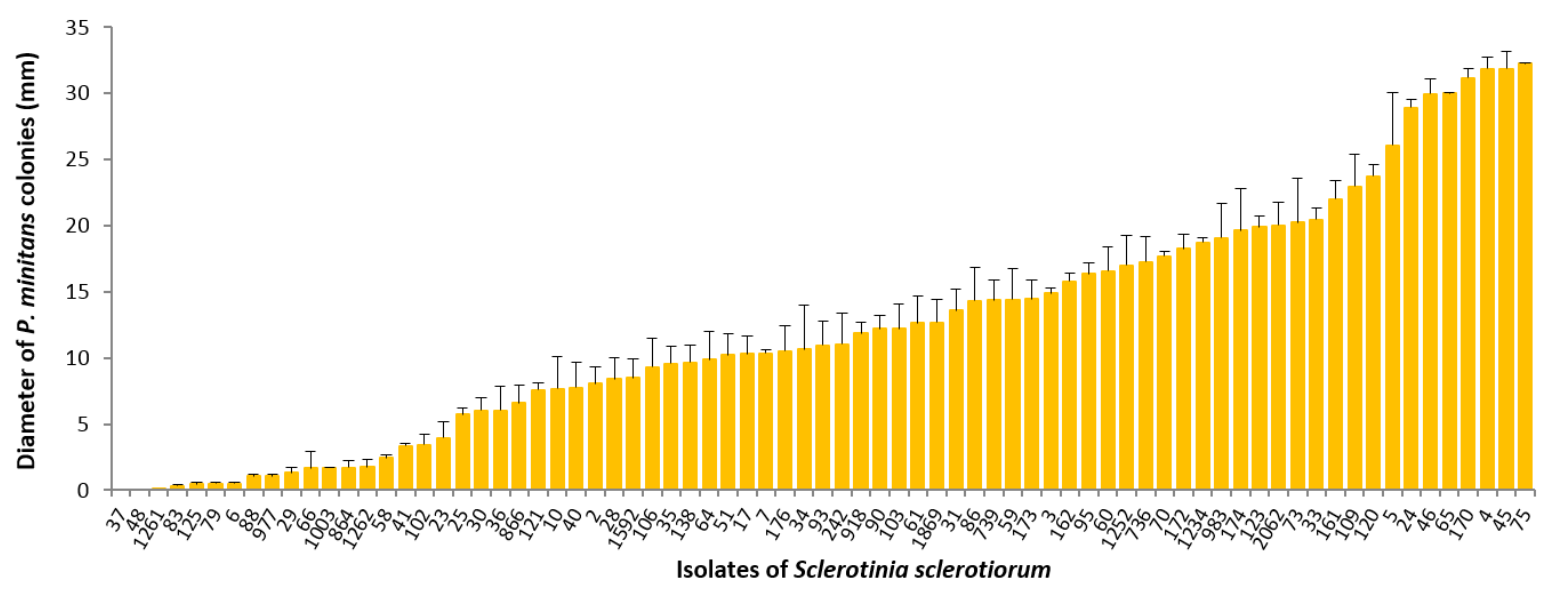

Figure 2: Diameter of Paraphaeosphaeria minitans colonies developed from inoculated sclerotia of 75 Sclerotinia sclerotiorum isolates incubated for seven days on PDA medium. Data represent averages for 60 half sclerotia \pm standard error of the mean. 


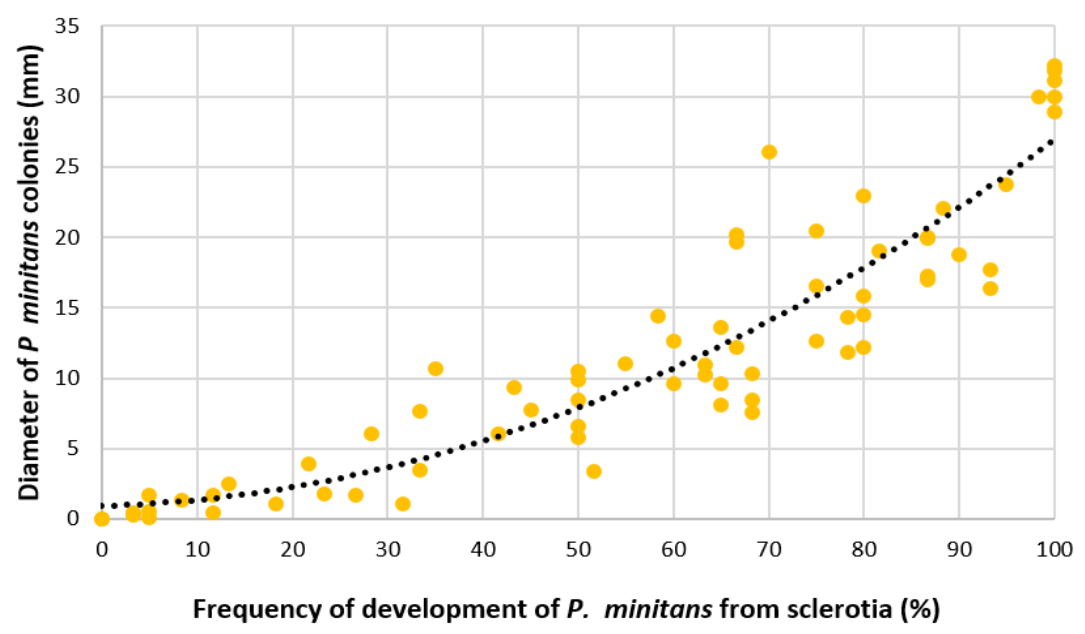

Figure 3: Relation between the frequency of development (\%) and the diameter of Paraphaeosphaeria minitans colonies (mm) developed from inoculated sclerotia of 75 Sclerotinia sclerotiorum isolates after seven days of incubation on PDA medium. The dotted line shows the best fit obtained from polynomial regression analysis.

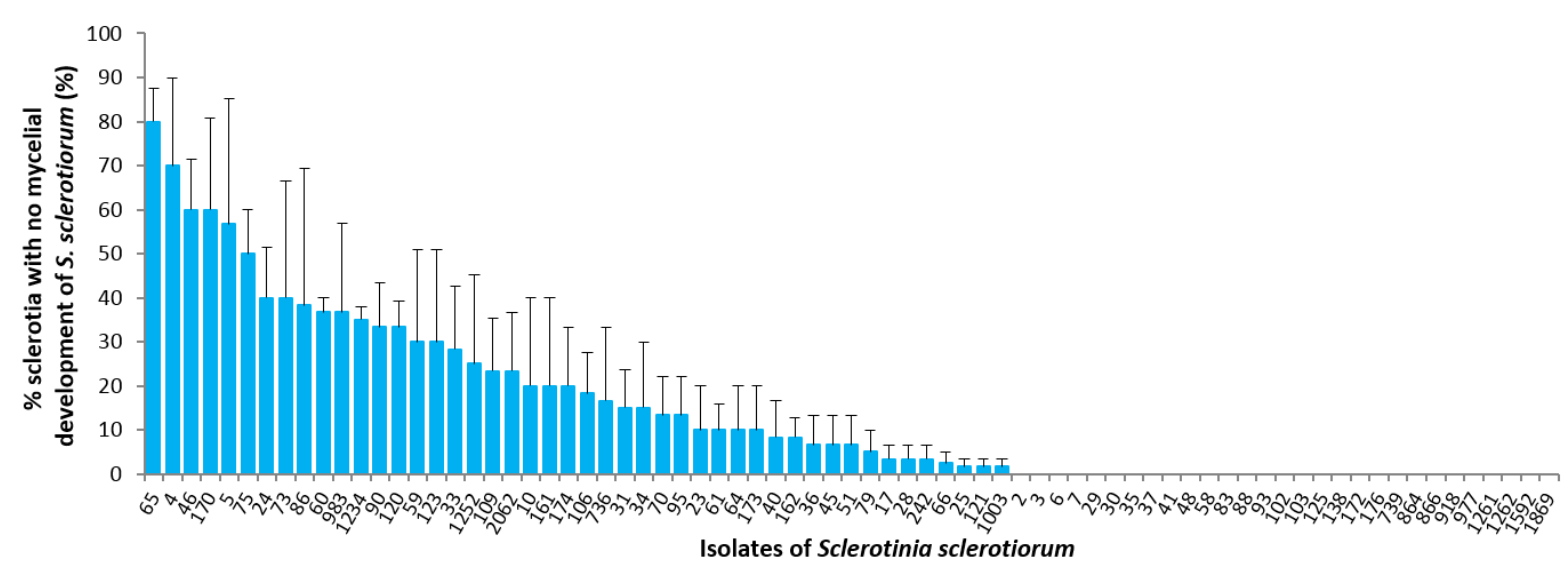

Figure 4: Frequency of absence of mycelial development of Sclerotinia sclerotiorum on PDA medium from sclerotia previously inoculated with Paraphaeosphaeria minitans. For each isolate, the data represent averages for three replicate batches of 20 half sclerotia \pm standard error of the mean. 

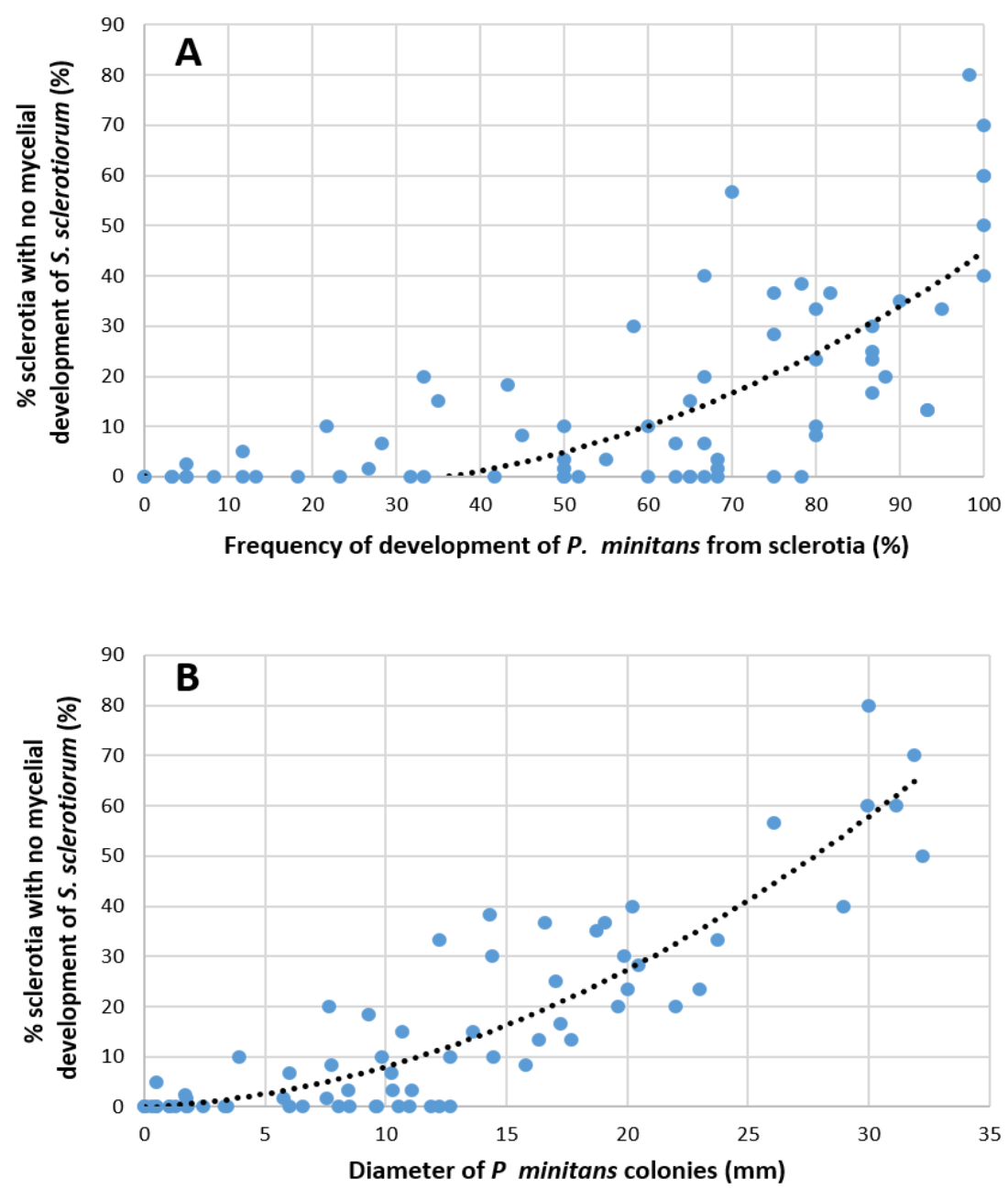

Figure 5: Relationship between the frequency of absence of Sclerotinia sclerotiorum development (\%) and (A) the frequency of development of Paraphaeosphaeria minitans (\%), or (B) the diameter of $P$. minitans colonies $(\mathrm{mm})$ developed from inoculated sclerotia of $75 \mathrm{~S}$. sclerotiorum isolates after seven days of incubation on PDA medium. The dotted lines show the best fits obtained from polynomial regression analysis. 


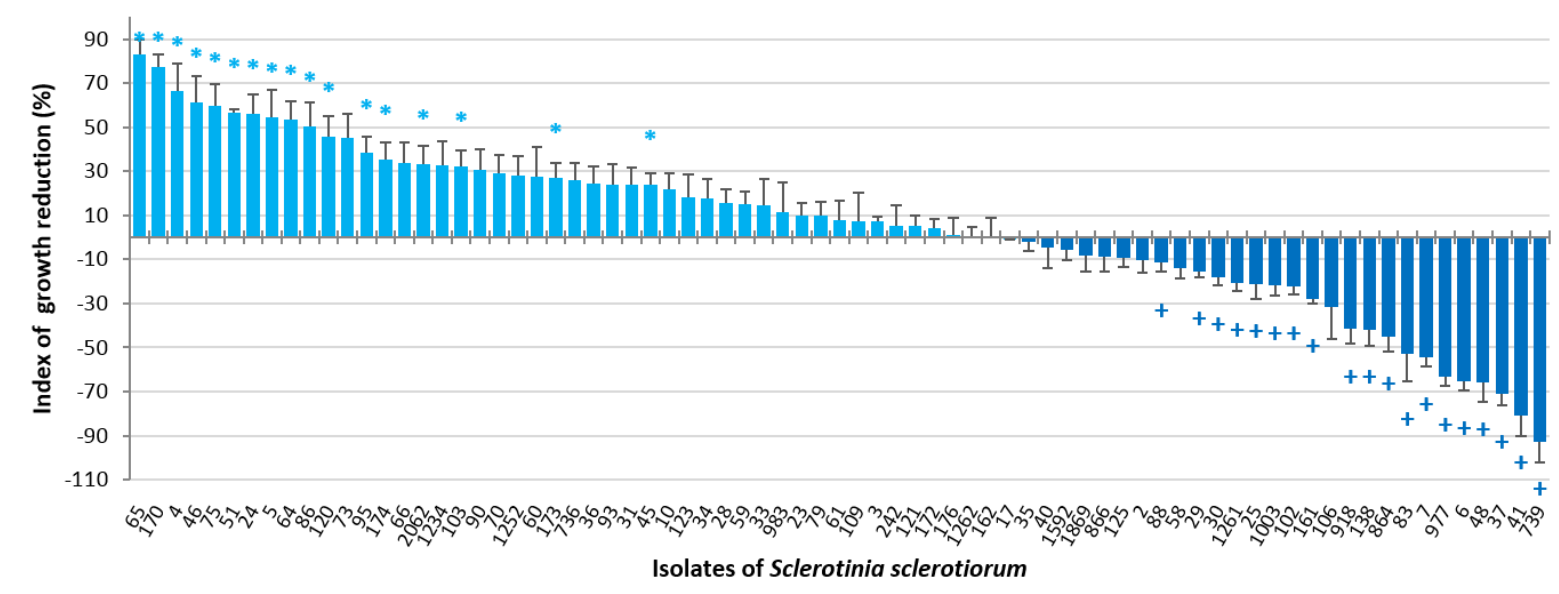

Figure 6: Reduction of mycelial growth of Sclerotinia sclerotiorum on PDA medium from sclerotia previously incubated with Paraphaeosphaeria minitans, relative to that from control non-inoculated sclerotia. Error bars indicate the standard error of the mean. For the 75 isolates of S. sclerotiorum, results of Wilcoxon-Mann-Whitney tests are shown to indicate significant reduction $(*$; light blue color) or increase (+; dark blue color) of colony diameter from inoculated sclerotia compared to non-inoculated controls $(P=0.05)$. 

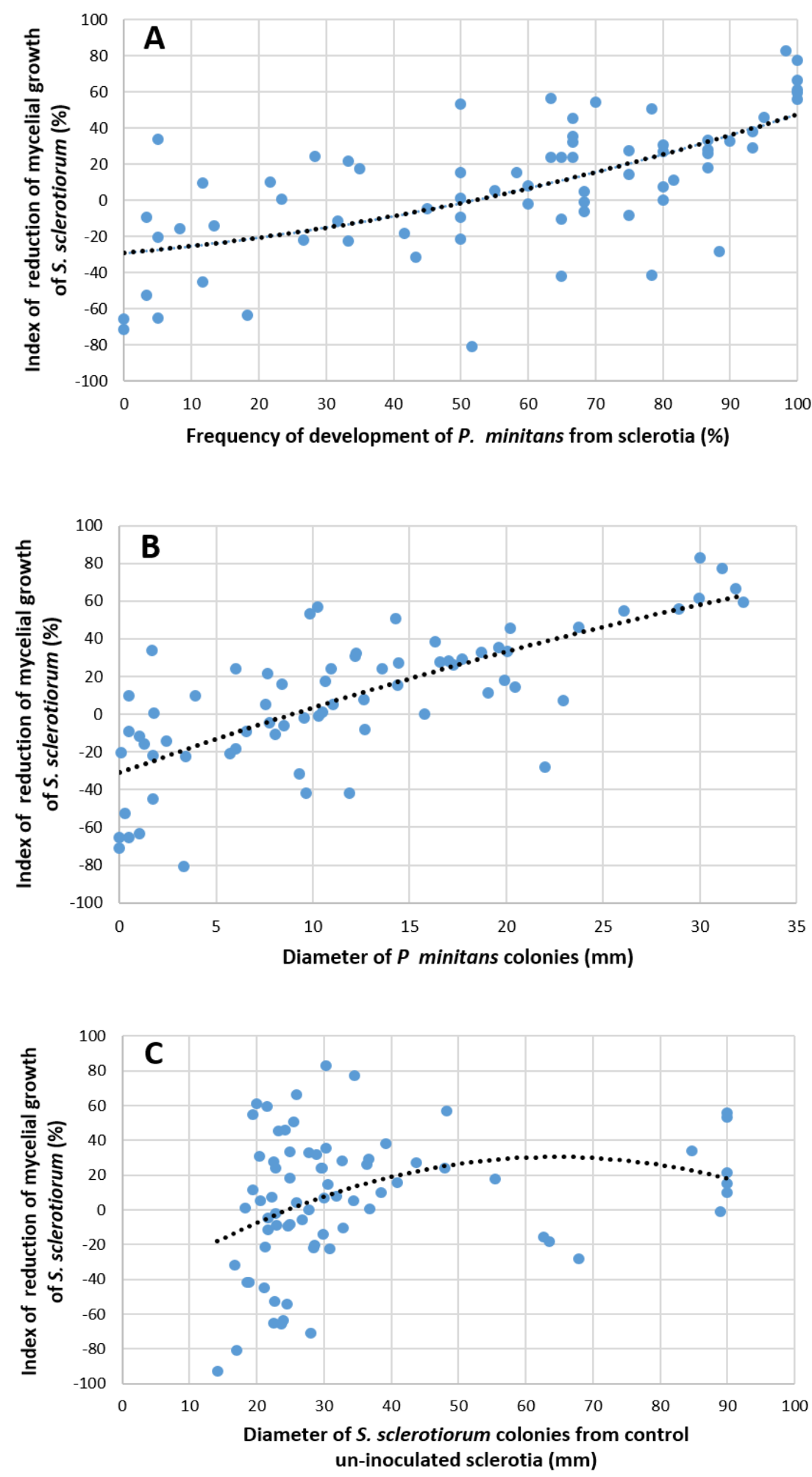

Figure 7: Relation between the reduction of mycelial growth of Sclerotinia sclerotiorum (\%) and (A): the frequency of development of Paraphaeosphaeria minitans (\%), (B): the diameter of $P$. minitans colonies (mm) developed from inoculated sclerotia of $75 \mathrm{~S}$. sclerotiorum isolates 
after seven days of incubation on PDA medium, or (C): the diameter of S. sclerotiorum colonies from non-inoculated sclerotia. The dotted lines show the best fits obtained from polynomial regression analysis. 


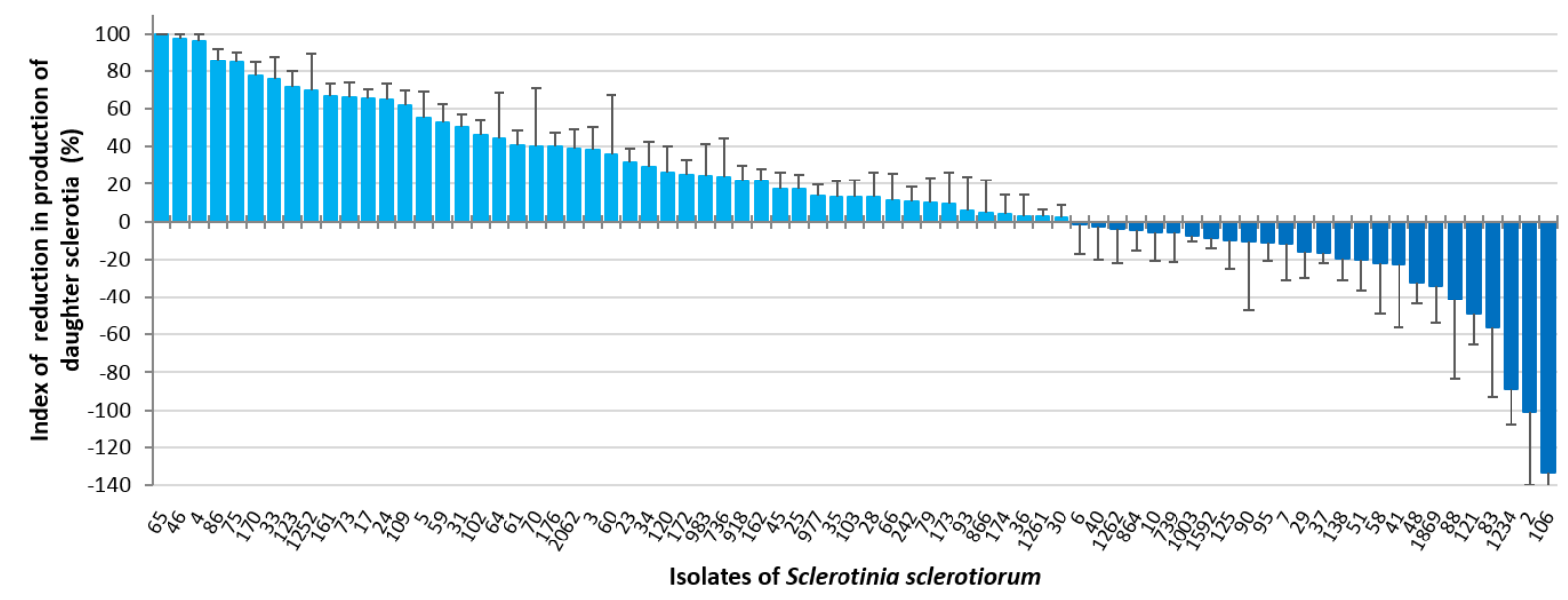

Figure 8: Reduction in production of daughter sclerotia by colonies of Sclerotinia sclerotiorum on PDA medium from sclerotia previously incubated with Paraphaeosphaeria minitans, relative to that from control non-inoculated sclerotia. Error bars indicate the standard error of the mean. 